[This is a pre-publication copy of an article accepted for publication in Classical Quarterly (02/05/2015)]

\title{
THE BOOK INDICES IN THE MANUSCRIPTS OF CASSIUS DIO*
}

\section{INTRODUCTION}

At some point before the late fifth century A.D. an unidentified writer compiled and affixed to each book of Dio's Roman History an index, most notably comprising a table of contents and an excerpt of the consular fasti. ${ }^{1}$ Of dubious provenance these

\footnotetext{
${ }^{*}$ I am most grateful to Chris Pelling, Nigel Wilson, Caillan Davenport, Helen Tanner, and the anonymous reviewer for their comments and advice on this paper. All mistakes and omissions are my own responsibility.

${ }^{1}$ Or so we may assume. Owing to the imperfect state of Dio's text, only twenty-three indices have survived in the manuscripts of Dio's work. For the manuscripts of Dio's history see discussion in Section I, below. All references to Dio are from U.P. Boissevain, Cassii Dionis Cocceiani Historiarum Romanarum quae supersunt (Berlin, 1898-1931). Where there is discrepancy between the 'traditional' book divisions (derived from the editions Leunclavius) and those of Boissevain, the 'traditional' book numbers will be placed in brackets ( ) after Boissevain's. For a succinct description of the two book numbering systems, see P.M. Swan, The Augustan Succession: An Historical Commentary on Cassius Dio's Roman History,
} Books 55-56 (9 B.C. - A.D. 14), (Oxford, 2004), 383-5. 
paratexts have played a peripheral role in the editorial history of the work. ${ }^{2}$ Bekker and Dindorf, with somewhat puritanical zeal, removed them from the main text of their editions of the Roman History in the belief that they were not by Dio's hand. ${ }^{3}$ Conversely, the stereotyped edition of Dio's history produced under the auspices of Karl Tauchnitz at Leipzig in 1818 provided Latin translations of the indices, but omitted the Greek. Dio's more recent editors have restored them to their editions of the Roman History, despite questions over their origins. ${ }^{4}$

The fate of the Dionian indices is indicative of editorial attitudes to such ancient paratextual material in general, and it is only lately that attention has been given to such texts. ${ }^{5}$ In a recent article, Gavin Kelly has shown the chapter headings

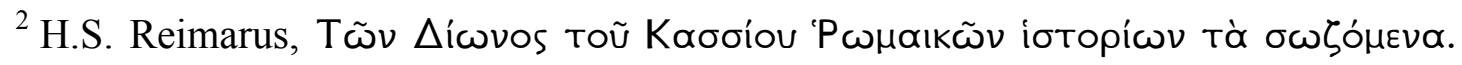
Cassii Dionis Historiae Romanae quae supersunt (Hamburg, 1750) 2.1538. The scholarly consensus is that they are not by Dio: Swan (n. 1), 33-4.

${ }^{3}$ L. Dindorf, Dionis Cassii Cocceiani Historia Romana (Leipzig, 1863-5), collected the indices with the addition of Latin summaries of Leunclavius (for those books which did not possess indices) at the beginning of the fifth volume of his edition of Dio's history. I. Bekker, Cassii Dionis Rerum Romanarum libri octoginta (Liepzig, 1849), banished them entirely.

${ }^{4}$ E.g. J. Melber, Dionis Cassii Cocceiani Historia Romana (Leipzig 1890-1928); Boissevain (n.1); E. Cary, Dio's Roman History (London 1914-27). This editorial practice applies to the ongoing Budé edition of Dio's work as well.

${ }^{5}$ For some general comments see R. Gibson, 'Starting with the index in Pliny', in Jansen, L. (ed.), The Roman Paratext. Frame, Text, Readers (Cambridge, 2014), 3355, at 38-9; cf. A. Favuzzi, 'L'ultimo libro di Cassio Dione', QS 15 (1989), 189-97, at $190-1$. 
included in the modern editions of Ammianus Marcellinus were the creation of the renaissance humanist Adrien de Valois (Hadrianus Valesius). ${ }^{6}$ Such a practice was not exceptional. Occasionally editors thought fit to replace the ancient summaries with those of their own: Jacob Spanmüller (Jacobus Pontanus) replaced the Greek summaries he found in the manuscripts of Theophylact Simocatta with his own (in Latin) and which in turn were adopted by Bekker in his edition of the seventh century historian. Even earlier, the fifteenth century translator of Diodorus Siculus, John Skelton translated into English the Latin indices of Gian Francesco Poggio Bracciolini, which Poggio had inserted in place of the original indices. ${ }^{7}$

Yet the decisions of editors such as Pontanus, Valesius, and Skelton reveal a fundamental truth about the function of indices. Namely they reflect the compiler's own reading of what constitute important points of interest within the text. Although the identity of the compiler of the Dionian indices is elusive, the antiquity of the indices is beyond dispute and thus they serve as an important guide to the early transmission and reception of Dio's history. This article offers a discussion of the form and content of the indices, and asks what these features might tell us about their compiler and, by extension, the tastes of the early readership of Dio's history, and the possible date of composition for the indices.

\section{FORM AND CONTENT}

${ }^{6}$ See G. Kelly, 'Adrien de Valois and the Chapter Headings of Ammianus Marcellinus', CPh 104 (2009), 233-42.

${ }^{7}$ For Skelton's translation which exists in one MS (Corpus Christi College, Cambridge 357) see the EETS edition by F.M. Salter and H.L.R. Edwards (edd.), The Bibliotheca Historica of Diodorus Siculus, translated by John Skelton (Oxford, 1955). 
The editorial practice of composing short epitomes intended to be prefixed to literary texts has a long antiquity. These paratextual epitomes may be broadly divided into two groups. The first may be classed as continuous prose summaries, such as the argumenta found in the manuscripts of Greek drama, the prologues of Pompeius Trogus, or the various epitomes of Livy. Such epitomes have a fairly loose connection with the main text. Indeed, some of these circulated independently of the main text. ${ }^{8}$ The second group comprises the more formulaic tabular indices, such as those found in the manuscripts of a diverse range of authors from Socrates Ecclesiasticus to Lucretius. These paratexts have a far closer relationship with the main text, and are unlikely to have circulated independently. It is in this group that the indices of Cassius Dio's history belong.

We know that some of these summaries originated with the author of the

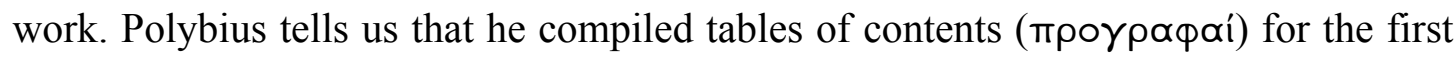

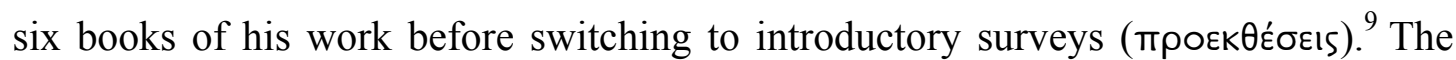

\footnotetext{
${ }^{8}$ As was the case with the Livian epitomes and the prologues of Trogus. For the transmission of the Periochae (which are preserved in the MSS of Florus), see M.D. Reeve, 'The Transmission of Florus' Epitoma de Tito Livio and the Periochae', $C Q$ 38 (1988), 477-91, and M.D. Reeve, 'The Transmission of Florus and the Periochae Again', CQ 41 (1991), 453-83. For Trogus' prologues, see O. Seel, Epitoma historiarum Philippicarum Pompei Trogi (Stuttgart, 1972), xiii-xiv.

${ }^{9}$ Polyb. 11.1a.1-5, with F.W. Walbank, A Historical Commentary on Polybius, Volume II (Oxford, 1967), 266-7. Polybius also tells us that the last book of his work seems to have functioned as a summary epilogue (Polyb. 39.8.8), but unfortunately
} 
elder Pliny and Aulus Gellius wrote their own tabular indices, but chose to include them at the beginning of their respective works. ${ }^{10}$ Other indices were added at a later date. It has been demonstrated recently that the indices found at the beginning of Books 4, 5, and 6 of the De Rerum Natura were compiled by an editor from marginal capitula, which in turn were the work of an earlier author. ${ }^{11}$ This method of composition may be peculiar to the Lucretian indices, but at the very least is suggestive of the possibility that other ancient indices may have been compiled in more than one stage of transmission. ${ }^{12}$

Three manuscripts of Dio's history are of particular relevance to this discussion. These will be referred to as $\mathrm{V}, \mathrm{M}$, and $\mathrm{L}$, following the classification of nothing is known of its layout or contents. For discussion of this passage, see F.W. Walbank, Polybius (Berkeley, 1972), 16-17 n. 82.

${ }^{10}$ Gell. NA praef. 25; Pliny HN praef. 33. For comments, see L. Holford-Strevens, Aulus Gellius: an Antonine Scholar and His Achievement (Oxford, 2003²), 30-1 (on Gellius); Gibson (n. 5), 34-6 (on Pliny).

${ }^{11}$ D. Butterfield, The Early Textual History of Lucretius' De Rerum Natura (Cambridge, 2013), 136-202.

${ }^{12}$ This might account for the temporal statements in the indices of Josephus' Jewish Antiquities, which must have been added at some point after the mid-fourth century date, and thus may post-date the book summaries. We know that Diodorus produced a summary of his work so as to guard against the circulation of unofficial copies of his history (Diod. Sic. 40.8; cf. 1.4.6-5.2), but the relationship (if any) between this and the book indices found in the MSS is uncertain. Be this as it may, it has been asserted that the indices were compiled by Diodorus himself: C. Rubincam 'How Many Books Did Diodorus Siculus Intend to Write?', CQ 48 (1998), 229-33, at 232 n. 15. 
Boissevain. ${ }^{13}$ The first and earliest of these (V) is a palimpsest preserved in codex Vaticanus graecus 1288. Of Italian provenance and dated to the late fifth century, the text contains a continuous albeit mutilated fragment belonging to Books 79(78)80(79) of the Roman History. ${ }^{14}$ The other two manuscripts are of a much later date and are both of likely Constantinopolitan origin. The tenth century codex Marcianus 395 (M), preserves the text of Books 44-60, albeit with several sizeable lacunae. ${ }^{15}$

${ }^{13}$ Boissevain (n. 1).

${ }^{14}$ For V, see P. Franchi de'Cavalieri, Cassii Dionis Historiarum Romanarum quae supersunt, Codex Vaticanus Graecus 1288 (Leipzig, 1908), 1-14; C.M. Mazzucchi, 'Alcune vicende della tradizione di Cassio Dione in epoca bizantina', Aevum 53 (1979), 94-134, esp. 94-122; cf. J. Irigoin, 'L'Italie méridionale et la tradition des textes antiques', JÖB 18 (1969), 37-55, at 44-5.

${ }^{15}$ Two lacunae are of particular relevance to this discussion. The loss of several folios which encompass the beginnings of Books 58 and 60 has resulted in the loss of the indices of those books. For the dating of M, see N.G. Wilson, Scholars of Byzantium (London, 1983), 139; Mazzucchi (n. 14), 125-6; cf. J. Irigoin, 'Centres de copie et bibliothèques', in Byzantine Books and Bookmen. A Dumbarton Oaks Colloquium (Washington, 1975), 17-27, at 22. A. Diller, 'Notes on Greek Codices of the Tenth Century', TAPhA 78 (1947), 184-8, at 184 n. 3, posited a ninth century date for M, similarly E. Mioni and M. Formentin (edd.), I codici greci in minuscola: dei sec. IXe X della Biblioteca nazionale marciana (Padua, 1975), 31; cf. M.-L. FreyburgerGalland, 'L'établissement du texte des livres $41 \& 42$ ', in M.-L. Freyburger-Galland, et al. (edd. and trans) Dion Cassius Histoire Romaine Livres 41 \& 42 (Paris, 2002), lxvi-lxix, at lxvi-lxvii. Yet this date seems too early. Mr. Nigel Wilson has drawn to my attention the fact that the hand of the scribe of $\mathrm{M}$ bears a strong similarity to that 
Finally, from the same century, codex Laurentianus plut. 70 n. 8 (L) preserves Books 36-50, but again imperfectly. ${ }^{16}$ Although we can be certain that $\mathrm{M}$ and $\mathrm{L}$ were not descended in any way from $\mathrm{V}$, the relationship between $\mathrm{M}$ and $\mathrm{L}$ is disputed, but it seems likely that they are both copies from the same exemplar. ${ }^{17}$

Typically the indices of other historical works are made up of two elements, a titulus followed by a summary of contents. ${ }^{18}$ The Dionian indices are different (indeed to my knowledge unique) in so far as they comprise four distinct elements: (i) a titulus stating the book number, the author, and the title of the work; (ii) a summary of the contents of the book in the form of a numbered series of short statements introduced

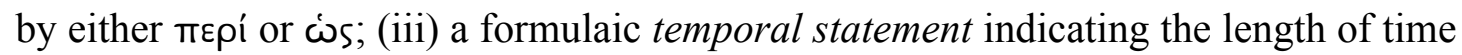
of the scribe of the Ravenna codex of Aristophanes (Biblioteca Classense, MS 429), which supports the assignment of a mid- to late-tenth century date to M. Similarly, against the dating of Mioni and Formentin, note Mazzucchi (n. 14), 126 n. 137.

${ }^{16}$ Here one lacuna is of particular relevance: the beginning of Book 36 (along with its index) is lost in L. For the date of L, see Diller (n. 15), 184-5; Irigoin (n. 15), 21; Wilson (n. 15), 139. A full digital facsimile of $\mathrm{L}$ is available via the Laurentian library website: http://www.bml.firenze.sbn.it.

${ }^{17}$ Boissevain (n. 1), lxxxvii. Subsequently it has been asserted that L might be a copy of M: Freyburger-Galland (n. 15), lxvi-lxvii; cf. Irigoin (n. 15), 22. This contention is based on the belief that $\mathrm{M}$ belongs to the latter ninth or early tenth century. If, however, $\mathrm{M}$ and $\mathrm{L}$ date to the same century, which seems likely, or if in fact $\mathrm{L}$ is earlier than M, as suggested by Wilson (n. 15), 139, then this position cannot be sustained. Either eventuality has no effect on the following argument.

${ }^{18}$ This is the format of the indices to the historical works of Diodorus Siculus, Socrates, Eusebius' Historia Ecclesiastica, Theophylact Simocatta, etc. 
covered in the book measured by years; and finally (iv) the corresponding consular fasti for those years. The index to Book 37 provides an illustration of this format: ${ }^{19}$

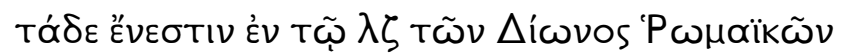

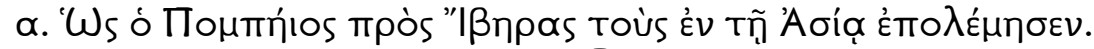

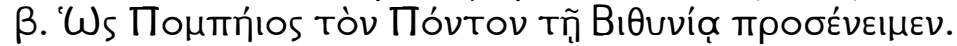

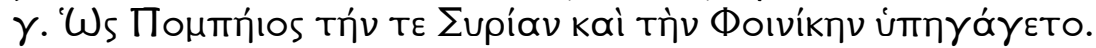

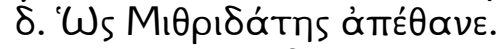



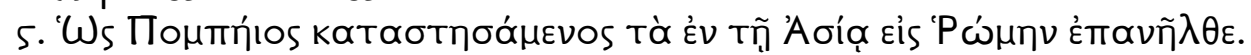

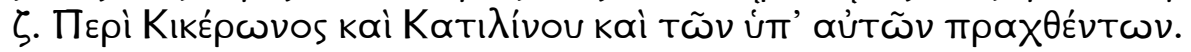

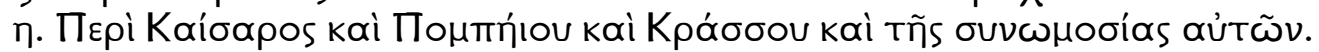

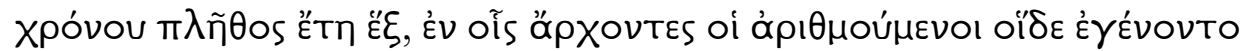

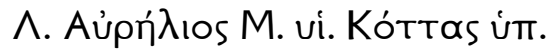

$\wedge$. Mád $\lambda \lambda \operatorname{los} \wedge$. vi. <Topkovãtos

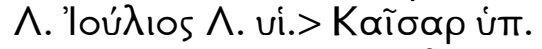

Г. Mápkios Г. vi. Фíyoùos

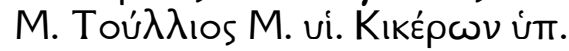

Г. Avтúvios M. vi.



$\wedge$. Aikívvios $\wedge$. vi. Mouprívas

M. Toúmios M. vi. Tíowv úr.

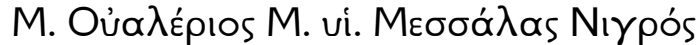

$<\Lambda$. > 'Aqpóvios Aǜ $\lambda$. vi. ưrim.

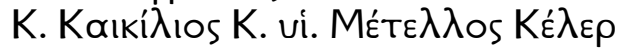

The fidelity to this general layout in our main authorities for Dio's text (V, M, and L) strongly suggests that the indices derive from a common archetype - at least with respect to the summaries, temporal statements, and the fasti. ${ }^{20}$ Whether the tituli were an original part of the archetype cannot be determined with certainty, but it is likely. ${ }^{21}$

${ }^{19}$ Cf. Boissevain (n. 1), 2.393.

${ }^{20}$ This is certain in the case of $\mathrm{L}$ and $\mathrm{M}$. There is no way of determining with any certainty whether the index in $\mathrm{V}$ is derived from the same archetype, but the presence of the characteristic temporal statement and the fasti suggests that it is. In later MSS, such as codex Laurentianus plut. 70 n. 10 (fifteenth century), the layout of the indices deviates from that found in L, M, and V (and especially in the presentation of the summaries). This variation seems to be scribal as codex Laurentianus plut. $70 \mathrm{n} .10$ is 
The apparent absence of a titulus in $\mathrm{V}$ requires explication. The transition between books in $\mathrm{V}$ is indicated by an apparent subscriptio $(\triangle \mathrm{I} \omega \mathrm{NO} \Sigma \mathrm{P} \omega \mathrm{MAIIKH} \Sigma$

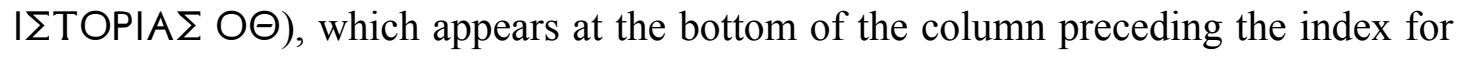
the following book. ${ }^{22}$ Whether this is indeed a subscriptio marking the end of Book 79 (that is, the explicit) or the titulus indicating the beginning of Book 79 is controversial, but the former seems more probable. If so, then it follows that the index refers to Book $80 .^{23}$ This might suggest that Book 80 never possessed a titulus, but we cannot be sure. V shows signs of damage where we would expect to find the titulus directly above the summary; hence it is possible that it has simply been lost. Moreover, $\mathrm{V}$ is a production of generally execrable quality, and it is equally likely that the scribe, nearing the end of the wearing task of copying Dio's vast work, omitted it from carelessness.

derived from both L and M: Boissevain (n.1) 1.lxxiv-lxxv; Freyburger-Galland (n. 15), lxvi-lxvii.

${ }^{21}$ Evidence suggests that it was important for a titulus to contain both the name of the author and the title of the work as a mark a work's genuineness: e.g. Galen, De Libris Propriis Praef. 1-2 Boudon-Millot $=19.8 \mathrm{Kuhn}$. For the convention of affixing titles (in the form of tags) to rolls, see E.G. Turner (rev. P. Parsons), Greek Manuscripts of the Ancient World, BICS Supp. 46 (1987), 13-14.

${ }^{22} \mathrm{~V}$ (fol. $\left.10^{\mathrm{v}}\right)=$ Franchi de'Cavalieri (n. 14), Plate 20. Each folium of V originally contained three columns of text. It should be noted also that in other MSS of Dio, similar subscriptions take the role of an explicit, denoting the number of the completed book (e.g. L, fol. $48^{\mathrm{v}}$ ).

${ }^{23}$ See Boissevain (n. 1), 3.viii-ix; cf. Mazzucchi, (n. 14), 97. 
The title statements found in $\mathrm{L}$ and $\mathrm{M}$ (and their recensions) are directly comparable to similar incipits found in other ancient indices, and so appear to conform to a standard convention. ${ }^{24}$ It is true that we find minor variation in the formula both within the individual manuscripts and between manuscripts, but it is not unusual to find such variations in the tituli of other ancient indices. The most common variation in the Dionian tituli is in the name of the work, variously written as

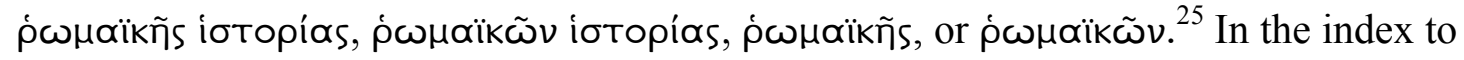
book 54 in $\mathrm{M}$ (fol. $155^{\mathrm{r}}$ ), the scribe even changes his regular convention for

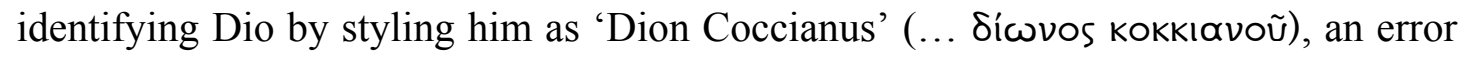
which must have originated with either the scribe of $M$ or an early Byzantine copy he was using for that book. ${ }^{26}$ Nevertheless, the tituli served important functions. They provided readers with fixed points of identification and reference from which they could orientate themselves within the Roman History. ${ }^{27}$ Moreover, the re-assertion of

${ }^{24}$ E.g. the indices to Josephus, Diodorus, Ptolemy, Socrates, etc., all contain the basic

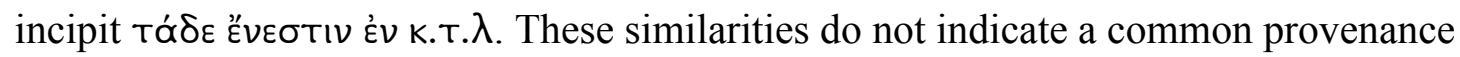
any more than the similarities of tables of contents or indices found in modern works.

${ }^{25}$ See Boissevain (n. 1), 1.lxiv, lxxiv for examples.

${ }^{26}$ For Dio's name, see Swan (n. 1), xiv; cf. A.M. Gowing, 'Dio's Name', CPh 85 (1990), 49-54; O. Salomies, 'Polyonymous Nomenclature in Consular Dating', Arctos 39 (2005), 103-35, at 108-9. The first known attestation of Dio as 'Dio Cocceianus' by Photius in the ninth century (Phot. Bib. cod. 71), but this was derived from an earlier source: Gowing (n. 26), 49.

${ }^{27}$ Especially important as the various books of the Roman History would have circulated initially either individually or in perhaps in clusters of several books. 
the author's name provided the text with credibility, a reminder (if one was needed) that they were reading Dio's history. ${ }^{28}$

The other elements appear to conform to an original formula. The summaries appear as either simple sentences introduced by ćs or prepositional or participle phrases introduced by $\pi \varepsilon \rho i$. Although such formulations were conventional, ${ }^{29}$ the compiler's fidelity to this formula demonstrates a rigidity that is somewhat atypical of comparable indices found in the Greek manuscripts of other ancient historians. In most cases, these statements introduce specific events or summarise an extended section of narrative (that is, a series of events). Occasionally the compiler introduces more complex constructions such as relative clauses (e.g. ind. 53, 80(79)). The vocabulary employed in these summaries offers few clues to authorship. In the main, the indices will employ slightly less technical vocabulary than found in the body text. Hence we find the notice of the dedication of the 'Precinct of Livia' described in the

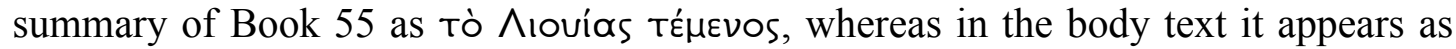

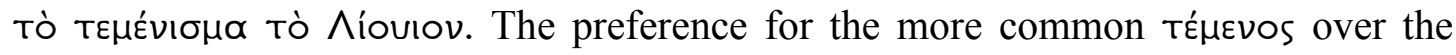

${ }^{28}$ The comments of G. Genette, (trans. J.E. Lewin), Paratexts: Thresholds of Interpretation (Cambridge, 1997), 41, seem especially apt: 'The author's name fulfils a contractual function whose importance varies greatly depending on genre: slight or non-existent in fiction, it is much greater in all kinds of referential writing, where the credibility of testimony, or of its transmission rests largely on the identity of the person reporting it $[\ldots]$ and this is all the more true when the witness himself plays a part in the narrative.'

${ }^{29}$ See further the (by no means exhaustive) comments of Regenbogen, $R E 20.2$

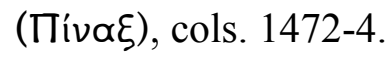


more obscure but typically Dionian $\tau \varepsilon \mu \varepsilon ́ v ı \sigma \mu \alpha$ is interesting, ${ }^{30}$ but is perhaps indicative of the desire of the author to maintain a degree of simplicity of expression. Even so, the compiler shows sympathy to Dio's more technical vocabulary. In the index to Book 80(79) the compiler uses Dio's characteristic word for Vestal Virgin

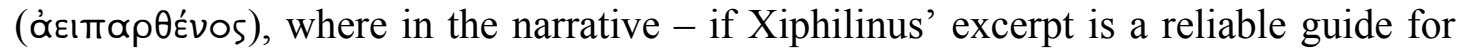
Dio's language, which in this case it probably is - Dio appears to have opted for



There occur many deviations both minor and major in orthography, and onomastic conventions, especially in the fasti sections between Dio's main text and the indices. Many of these deviations are likely to be the result of corruption in the process of textual transmission. ${ }^{32}$ On one notable occasion the compiler employs a

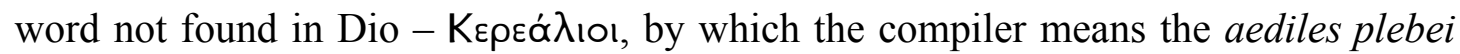

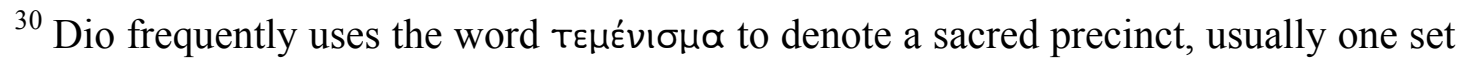
aside for an emperor or a member of the imperial family. His usage is also unusual: of

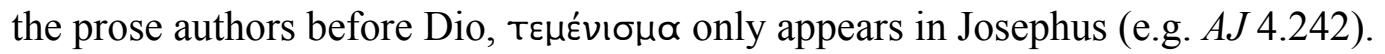

${ }^{31}$ 80(79).9.3. Elsewhere, Xiphilinus shows no reluctance in using áєıтар日évos (e.g. Xiph. $333.29=78(77) .16 .1$; Xiph. $218.18=67.3 .3)$, which suggests the wording at 80(79).9.3 is close (if not identical) to Dio's original.

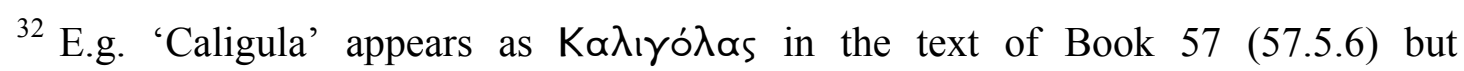
$\operatorname{K} \propto \lambda \lambda_{\text {ı }}$ ó $\lambda \propto{ }_{s}$ in the index to Book 58. The error is likely to be the result of scribal


(58.1.1). All examples come from M. For discussion of the Dionian fasti, see Section II, below. 
Cereales. ${ }^{33}$ For the passage in question (43.51.3), Dio scrupulously avoided such a

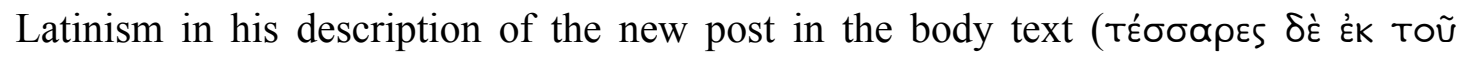

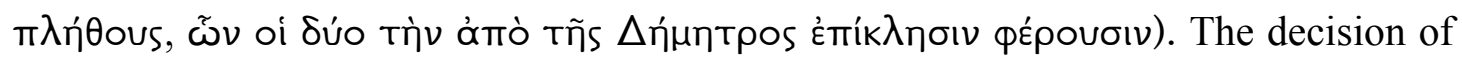
the compiler is intriguing, and if nothing else, points at least to the compiler possessing a degree of bilingualism. Moreover, the compiler's method of transliteration is not dissimilar to that used elsewhere by Dio to describe quintessentially 'Roman' ideas or institutions. ${ }^{34}$

The summaries present us with problems of interpretation. In general terms, an epitome exists to summarize and condense. Detail gives way to generalisation in an attempt to establish a sense of historical narrative. The summaries in the Dionian indices are different. They often provide the detail but without the context. Examination of the summaries themselves indicates further characteristics of the compiler's method and raises questions about their function. As the following table shows, there is no correspondence whatsoever between either the length of the book or the years covered in the book, and the number of items included in the summaries.

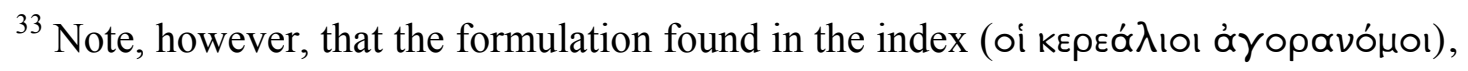
while unattested in literary sources, is paralleled on an honorific statue base from Western Anatolia (Akmoneia) commemorating a certain T. Fl. Montanus

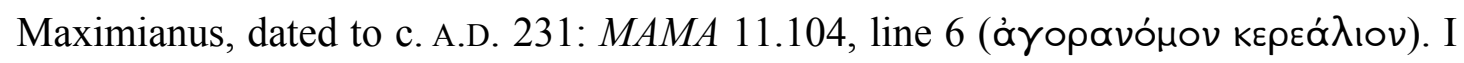
thank Caillan Davenport for bringing this inscription to my attention.

${ }^{34}$ Cf. M.-L. Freyburger-Galland, Aspects du vocabulaire politique et institutionnel de Dion Cassius (Paris, 1997), 163, who draws attention to adoption of the Latinism in Dio's description of the aediles curules at 39.32 .2 (mepi toùs á̀yopavómous toùs koupou入íous). For a list of Dio's transliterations, see Nawjan's vocabula latina in his index to Boissevain's edition: Boissevain (n. 1), 5.[880]). 


\begin{tabular}{|c|c|c|c|}
\hline Book & Number of Items & Years Covered & Pages (Boissevain) \\
\hline 37 & 8 & 6 & 34 \\
\hline 38 & 4 & 2 & 38 \\
\hline 39 & 11 & 4 & 34 \\
\hline 40 & 8 & $41 / 2$ & 37 \\
\hline 41 & 5 & 2 & 37 \\
\hline 42 & 8 & $1 \frac{1}{2}$ & 33 \\
\hline 43 & 10 & 3 & 33 \\
\hline 44 & 5 & $1 / 2$ & 34 \\
\hline 45 & 4 & $1 / 2$ & 31 \\
\hline 46 & 4 & 1 & 36 \\
\hline 47 & 3 & 1 & 36 \\
\hline 48 & 7 & 5 & 42 \\
\hline 49 & 7 & 4 & 33 \\
\hline 50 & 2 & 2 & 27 \\
\hline 51 & 7 & $2^{1 / 2}$ & 26 \\
\hline $52 *$ & 2 & $1 / 2$ & 33 \\
\hline 53 & 12 & 6 & 28 \\
\hline 54 & 9 & 13 & 34 \\
\hline $55^{*}$ & 13 & 17 & 41 \\
\hline $56^{*}$ & 5 & 6 & 38 \\
\hline $57^{*}$ & 4 & 11 & 29 \\
\hline $59^{*}$ & 4 & $3^{1 / 2}$ & 44 \\
\hline $80^{*}$ & 6 & $4 \frac{1}{2}$ & 21 \\
\hline
\end{tabular}


* Denotes books which contain significant lacunae.

No text, especially one as lengthy and as complex as Dio's, can be satisfactorily reduced to a table of contents. But if the function of the summaries was to provide the reader with a general indication of the content of each book then the compiler failed absolutely in his venture. Unlike the fulsome summaries found in the manuscripts of Josephus and Diodorus which give a generally accurate indication of the narrative content of the particular book, the Dionian summaries provide but a seemingly erratic sample of the narrative content. ${ }^{35}$ Nevertheless, there is a certain degree of consistency in the sorts of things that the compiler registers in the summaries.

Wars, the annexation of territory, civil conflicts and the dedications of buildings at Rome are the commonest details supplied in the summaries. Coupled with the inclusion of the fasti, the compiler reveals himself to be very much in sympathy with the basic elements of annalistic historiography. In the recording of conflicts and annexations, the compiler's tastes are similar to those of the author of the Periochae. ${ }^{36}$ This is hardly surprising as such details were the basis of Dio's (and Livy's) historical narrative. But with respect to the buildings, the Dionian indices reveal a set of peculiarly antiquarian concerns distinct from the epitomators and chroniclers of the century after Dio. We may compare the indices of books 38-55,

${ }^{35}$ For comparison, the index to Book 13 of Diodorus has 48 items and the index to Book 1 of Josephus' Jewish Antiquities has 19 items.

${ }^{36}$ Interestingly, there is no mention of the celebration of triumphs in the Dionian summaries: cf. J.D. Chaplin, 'The Livian Periochae and the Last Republican Writer', in M. Horster, and C. Reitz (edd.), Condensing Texts - Condensed Texts, (Stuttgart, 2010), 451-67, at 456 . 
which cover the years 59 B.C. -8 B.C., with the corresponding sections of the Periochae. Our compiler records the dedications of eighteen buildings, all at Rome. None is preserved in the Periochae. ${ }^{37}$ Indeed, the building programmes of the Late Republic generally pass without comment in fourth century sources: the only reference to appear in the Chronicle of Eusebius-Jerome is the dedication of the Basilica Iulia. $^{38}$

Other inclusions are of an essentially non-annalistic nature. Some are trivial. Dio's ethnographic and geographical digressions such as on the customs of the Jews, the Parthians, and Dio's description of the region around Baiae make their way into the summaries. ${ }^{39}$ Yet these trivialities are relatively few and the compiler's mind is usually preoccupied with matters more weighty. ${ }^{40}$ In particular the compiler shows an interest in recording administrative developments, such as the appointment of the aforementioned aediles Cereales (ind. 43), the selection of road and grain commissioners (ind. 54), the method of appointing provincial governors (ind. 53), the establishment of the vigiles (ind. 55), and the deployment of the legions (ind. 55). We are even informed about the institution of the Augustalia (ind. 54). In a similar vein,

\footnotetext{
${ }^{37}$ The same is true for the corresponding sections of other works derived from Livy, such as Eutropius' Breviarium.

${ }^{38}$ Hieron. Chron. p. 156 (ed. Helm).

${ }^{39}$ Jews: Cass. Dio ind. 37; Parthians: Cass. Dio ind. 40; Baiae: Cass. Dio ind. 48

${ }^{40}$ Although such exercises in erudition might be said to be trivial, ethnographic or geographical digressions were, of course, an important feature of Greco-Roman historiography. For an overview, see R.F. Thomas, Lands and Peoples in Roman Poetry: The Ethnographical Tradition, PCPhS Supp. 7, (Cambridge, 1982), 1-5; and for Dio specifically, F.G.B. Millar, A Study of Cassius Dio (Oxford, 1964), 177-9.
} 
the compiler draws the reader's attention to Caesar's (sc. Octavian's) adoption of the name Augustus and Dio's discussion 'about the titles which the emperors assume'

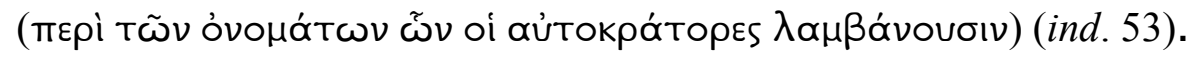

Just as these inclusions are instructive in determining the character of the indices, so too are the omissions. The compiler shows no interest at all in recording the many omens and natural phenomena that adorn Dio's narrative. Why this should be the case is uncertain. The evidence of the Periochae, not to mention the strange catalogue of prodigies extracted from Livy by Julius Obsequens at some point between the second and fifth centuries, ${ }^{41}$ suggests that there was an enduring appetite for such tales amongst late-antique readers. ${ }^{42}$ For Dio in particular, the occurrence of portents was indicative of the divine awareness of human affairs while also functioning as significant textual markers, denoting historical and narrative transitions. $^{43}$

References to the set-piece speeches that Dio included in his work are sporadic. The compiler notes eight of the eighteen speeches which occur in the twenty-three books that possess summaries. ${ }^{44}$ The compiler records five speeches

${ }^{41}$ For the date of Obsequens, see now A. Cameron, The Last Pagans of Rome (Oxford, 2011), 225.

${ }^{42}$ Points of comparison and contrast can be made here with the Periochae, where the author generally ignores Livy's catalogues of portents, but includes some individual portents: e.g. Livy Per. 55; cf. Chaplin (n. 36), 453 n. 7.

${ }^{43}$ Cf. Millar (n. 40), 77; J.W. Rich, Cassius Dio: The Augustan Settlement (Roman History 53-55.9) (Warminister, 1990), 12; Swan (n. 1), 8-13.

${ }^{44}$ For the list of speeches in Books 37-56, see $R E 3$ (Cassius 40), cols. 1718-19 (Schwartz). 
from the Republican books: the Cicero-Philiscus dialogue in Book 38, the funeral oration for Caesar in Book 44, the speech of Cicero against Antony in book 45 and the reply speech of Calenus in Book 46. Three of the Augustan speeches are noted: Augustus' speech to the Senate in Book 53, the Livia-Augustus dialogue in Book 55 and finally Augustus' speech to the unmarried equites in Book 56. All are worthy speeches, but the omissions are noteworthy. None of the Caesarian speeches caught the compiler's eye. Most surprisingly, the Agrippa-Maecenas debate passes without direct comment. The compiler's selection defies ready explanation. It is unlikely that the compiler's choice of speeches was governed by overarching thematic concerns, ${ }^{45}$ although it is true that the inclusion of the two dialogues might have owed something to their timeless philosophical themes. ${ }^{46}$ As for the other speeches, it is possible that they were simply speeches that the compiler thought particularly noteworthy in terms of style or subject. This might account for the fact that three of the four Republican speeches are either delivered by or involve Cicero in some way.

In a recent study, Chaplin has demonstrated how the author of the Periochae 'tracks' particular individuals. ${ }^{47}$ This is at least partially true for the Dionian indices, but it is less overt. Certainly the compiler shows an interest in tracking the actions of the dominant figures of Dio's history: Caesar, Cicero, Pompey, Augustus, and Tiberius, but this is only to be expected. In the case of Tiberius, we may see clearly

${ }^{45}$ As was the case with Xiphilinus' choice of speeches: C.T. Mallan, 'The Style, Method, and Programme of Xiphilinus' Epitome of Cassius Dio’s Roman History,' GRBS 53 (2013), 610-44, at 618-21.

${ }^{46}$ Moreover, it is possible that these dialogues were deemed more suitable for the purposes of recitation than, say, the Agrippa-Maecenas set piece.

${ }^{47}$ Chaplin (n. 36), 460-3. 
that the compiler follows Tiberius' early career on account of his being a future emperor. Hence, we are told about his self-imposed exile to Rhodes, about his adoption by Augustus, and his ensuing campaigns (ind. 55). The younger Cato, a man of especial interest for Dio, appears only twice - with reference to his spectacular death at Utica (ind. 43) and before that to his term as governor of Cyprus (ind. 39). ${ }^{48}$ Unlike the author of the Periochae there is little comment on the character of any of the individuals mentioned in the indices. With perhaps two exceptions the compiler is interested in individuals as political players, not as personalities. In the republican indices, Dio's analysis of historical trends or institutional conflicts is reduced and refocussed in terms of conflict between two individuals. Hence, in the index to book 38 the compiler lists the first item as 'How Caesar and Bibulus quarrelled' (c่s

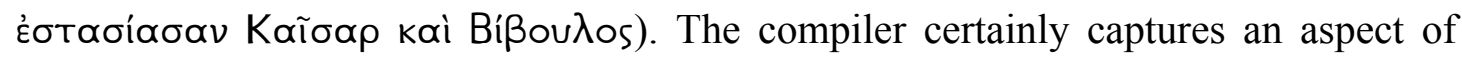
Dio's narrative (38.6), as well as an important part of the historiographical tradition concerning Caesar's consulship, ${ }^{49}$ but it seems to miss the central focus of Dio's narrative which is Caesar's defiance of the Senate in achieving his legislative programme.

The compiler occasionally indicates those parts of the narrative where Dio provides a character-sketch of an important individual. The first is in the index to Book 55 where the author notes how Augustus became more merciful as a result of taking advice from Livia. The second is in the summary to Book 80(79), which reads:



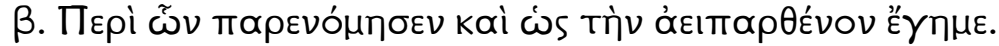

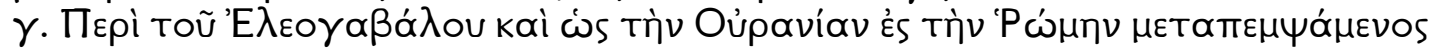

${ }^{48}$ Both were exemplary: 43.10.1-11.6; 39.22.1-23.4; cf. Plut. Cato min. 38; Livy Per. $104,114$.

${ }^{49}$ E.g. Livy Per. 103; Plut. Cato min. 32.1-2, Caes. 14.9; Suet. Iul. 20.1-2; etc. 




$\delta$. Пврі тก̃

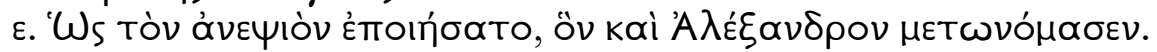

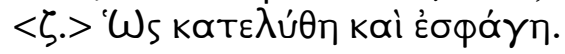

The casualness of expression is unusual, and the attention given to the emperor's habits is perhaps significant. Certainly the author manages to signal accurately the three main components of Dio's portrayal of the emperor (we call) Elagabalus - his 'bloodthirstiness', his 'lawlessness', and his 'licentiousness'. But we may ask why this should be the case here but not for other imperial figures where Dio follows a similarly schematic approach, for example Tiberius in Book 57 or Caligula in Book 59. A solution might lie in the fact that Dio's portrayal of the emperor Elagabalus is one of the most striking in the Roman History. It may have been that the lurid details of the debauched stripling's life of deviancy caught the eye of the summariser who had reached the end of his task. As we have already seen, the inclusion of Calenus' invective against Cicero in the index of Book 46, a speech of little historical relevance but which is a model of vituperative discourse, perhaps indicates a fondness of our summariser for invective. But if this is the case, then it can only be part of the answer.

In some cases, our compiler regarded an individual's death as more important than his deeds while alive - another feature in common with the annalistic and chronographic traditions. For example, in the Augustan and Tiberian books the compiler notes the deaths of Agrippa (ind. 54), the elder Drusus (ind. 55), Gaius and Lucius Caesar (ind. 55), Quinctilius Varus (ind. 56), Germanicus (ind. 57), the younger Drusus (ind. 57), without reference to their actions, although that might have been expected at least in the cases of Germanicus and the elder Drusus. At other times some significant deaths pass unnoticed. Given the author's apparent interest in the Ciceronian speeches and at least some interest in Cicero's career, it is curious that there is no specific mention of Cicero's death. 
We may infer that the method of compiling these summaries was simple and laborious. The compiler must have trawled through Dio's text noting down items that were of interest either to himself or to a patron. These were then tabulated and copied into the manuscript that was being prepared. That this was the compiler's method can be demonstrated simply with reference to his adherence to Dio's convention of naming Augustus. Up to the index of Book 53, the compiler follows Dio's (historically correct) decision to refer to Caesar's heir simply as 'Caesar'. ${ }^{50}$ After that, the compiler, like Dio, refers to him as 'Augustus'.

\section{THE CONSULAR FASTI}

Given this method of composition, it would have been simple enough for the compiler to excerpt the names of the consuls as they appeared in Dio's text and tabulated them for the indices, while also keeping a tally of the passing of the years for his chronological statements. This however cannot be the way the compiler worked. Long ago Reimar noted the discrepancies in the order of the consuls listed in the body text and in the fasti, and inferred that the author of the indices could not be Dio. ${ }^{51}$ Prima




statement at 45.5.1.

${ }^{51}$ Reimarus (n. 2), 2.1538, cf. 1.340 (on the index to Book 43). Note also the omission of the consuls Pansa and Hirtius in the fasti attached to Book 45 (cf. 45.17.1). For examples of the various literary and epigraphic fasti for the years 65 B.C. - A.D. 13 see the tabulation of A. Degrassi (ed.), Inscriptiones Italiae Academiae
} 
facie, this basic assertion appears to be sound - but only so far as it proves that the fasti could not have been compiled from Dio's main narrative. The fasti show the use of a secondary source which provided more information than that given in the body text, noting the consuls' filiation, instances of consular iteration, dictatorships and appointments to the position of magister equitum. ${ }^{52}$ Why and when this interpolation should have taken place is by no means clear.

The inclusion of the fasti reveals two obvious but fundamental characteristics of the indices, namely their specifically Roman character, ${ }^{53}$ and the concern of our compiler for reconciling the text of Dio's history to a standard reckoning of time. This preoccupation with time can be observed elsewhere. On occasion the compiler attempts to clarify any apparent inconsistencies between the general temporal statement and the list of consuls. ${ }^{54}$ Like Dio himself, the compiler of the indices by including the consular fasti seems to have operated consciously within the Roman annalistic tradition and eschews other sources of dating, such as Olympiads or regnal

Italicae Consociatae ediderunt. Volumen XIII, Fasciculus I: Fasti consulares et triumphales (Rome, 1947), 489-533.

${ }^{52}$ For the latter two categories, see Cass. Dio ind. 42, ind. 43, ind. 44, ind. 45.

${ }^{53}$ Note the comments of R.W. Burgess and M. Kulikowski, Mosaics of Time: The Latin Chronicle Traditions from the First Century BC to the Sixth Century AD. Volume 1: A Historical Introduction to the Chronicle Genre From its Origins to the High Middle Ages (Turnhout, 2013), 158-9, on the 'Romanness' of consular dating.

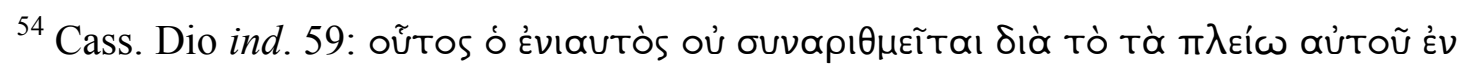
$T \tilde{\varphi} \xi^{\prime} \gamma \varepsilon \gamma \rho \alpha ́ \alpha \theta \propto \alpha$ I. 
years. ${ }^{55}$ That he should do so was by no means inevitable. The fourth century author of the Periochae, despite the annalistic nature of the source-text, was little concerned with such matters and preserves only the loosest sense of chronology. By way of contrast, the third century compiler of the so-called Oxyrhynchus Epitome of Livy recorded the names of the consuls before providing his summaries of the particular year. ${ }^{56}$ Among compilers of indices written in Greek, our compiler's interest in the accurate presentation of time is largely unique to him; the compilers of the analogous summaries found in Diodorus, Eusebius' Ecclesiastical History, and Theophylact Simocatta (for example) show scant attention to such details. The exception is the compiler of the summaries to Josephus' Jewish Antiquities, who affixed a temporal statement (which was interpolated from Eusebius) to the end of each summary indicating the number of years covered in the book. ${ }^{57}$

The names of contemporary consuls (ordinarii and suffecti) were widely circulated for administrative purposes. A late fourth century legal text indicates that such details were disseminated at the beginning of each year by the chancellery and it

${ }^{55}$ As far as we can judge from our fragmentary text, Dio seems to have maintained his annalistic structure with consular dating throughout his work. It is worth noting that Dio's own calculation of regnal years for the imperial books was assiduous: W. Snyder, 'On Chronology in the Imperial Books of Cassius Dio's Roman History', Klio 33 (1940), 39-56. Only once (in the extant text) does Dio resort to using Olympiads: Cass. Dio F 32.

${ }^{56}$ First published as P.Oxy. 4. 668. It may be noted that Obsequens too organised his catalogue of portents according to consular years.

${ }^{57}$ Whether these statements were part of the original summaries or added at a later time is unknown. 
is likely that such a method of dissemination existed in the centuries before. ${ }^{58}$ But consular lists including full sequences of names were a different matter. ${ }^{59}$ The compilation of such documents was primarily the work of individuals, not of bureaucracies. Indeed the Dionian fasti are unique texts, and display an extraordinary degree of antiquarian industry and erudition. The sheer level of recherché detail in the consular fasti found in the Dionian indices is absent from surviving consular lists from the fourth, fifth, and sixth centuries. Importantly, the manner in which the Dionian fasti is presented is totally anomalous to the conventions of the fourth and fifth centuries, from which many examples survive. Both the consularia and unannotated consular lists from the fourth century and after conventionally identify the consuls by either cognomen (or agnomen) or nomen gentilicium alone. ${ }^{60}$ Even the best of these works, the Chronograph of 354, stops recording praenomina (in any case

${ }^{58}$ Cod. Theod. 8.11.2, 3; cf. R.S. Bagnall, A. Cameron, S.R. Schwartz, K.A. Worp, Consuls of the Later Roman Empire (Atlanta, 1987), 26.

${ }^{59}$ For which, see in general R.W. Burgess, The Chronicle of Hydatius and the Consularia Constantinopolitana (Oxford, 1993), 175-86; Burgess and Kulikowski (n. 53), 136-7.

${ }^{60}$ Cassiod. Chron. 634/31 [= Chron. Min. 2. p. 136]. According to R.W. Burgess, "Non duo Antonini sed duo Augusti': The Consuls of 161 and the Origins and Traditions of the Latin Consular Fasti of the Roman Empire', ZPE 132 (2000), 25990 , at 261-3, this became conventional after the middle of the third century. See further, Burgess and Kulikowski (n. 53), 133-4; cf. Salomies (n. 26), 105-6 n. 10. For the shift away from the use of the praenomen more generally, see B. Salway, 'What's in a Name? A Survey of Roman Onomastic Practice from c. 700 B.C. to A.D. 700', JRS 84 (1994), 124-45, at 130-1, and passim. 
irregularly noted) from the middle of the first century A.D., and Cassiodorus abandons the recording of the consuls' praenomina from A.D. 31 onwards. ${ }^{61}$ Furthermore, there is not to my knowledge a surviving non-lapidary consular list that provides the consuls' filiation, a practice which the compiler maintains at least until the consuls of A.D. 41 (ind. 59). ${ }^{62}$

Although not immune to errors, the compiler of the fasti seems to have approached his task with the sort of due care and attention suitable for a prosopographer. Three times he shows hesitancy in assigning cognomina to consuls. Two such instances occur in the fasti affixed to Book 57. A consul of A.D. 17 is styled

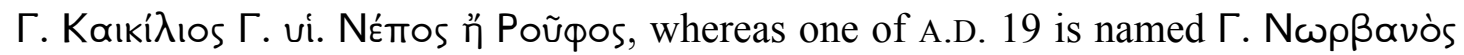

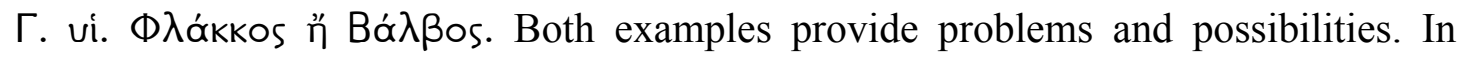
accordance with other sources, the trumpet-playing consul of 19 appears in the body text as 'Lucius Norbanus' (57.18.3). This man was the brother of C. Norbanus Flaccus, the consul of 15 . We might suspect scribal error as the cause of the confusion of his praenomen. After all, only a few lines separated the Lucius Norbanus from his older brother, and it would have been easy enough to make the mistake of writing $\Gamma$. instead of $\wedge$. for the consul of 19 . But the hesitancy as to whether his cognomen was Flaccus or Balbus might well stem from the error of the compiler himself and his uncertainly over the relationship between the two consular Norbani ${ }^{63}$ - unless, that is,

${ }^{61}$ Which was the point at which Cassiodorus began following the fasti recorded by Victorius of Aquitaine: Burgess (n. 60), 260.

${ }^{62}$ This applies to non-imperial consuls only. For the years 219-222 (Cass. Dio ind. 80(79)), the fasti cease to cite filiation, but continue to name the non-imperial consuls with full tria nomina.

${ }^{63} P I R^{2} \mathrm{~N} 165$. 
the consul of 19 was (as Boissevain suggested) a polyonymus and the compiler recognised the fact. ${ }^{64} \mathrm{~A}$ similar possibility presents itself in the case of the consul of 17. As with the fasti, Dio names the consul 'Gaius Caecilius' in the body of the text (57.17.1), whereas he is named elsewhere as Gaius Caelius. ${ }^{65}$ Again corruption may be suspected, but this again would not explain the alternative cognomina. Another polyonymous consul may be the answer. ${ }^{66}$

The nomenclature of emperors and princes in the fasti is often idiosyncratic. Occasionally there are inconsistencies: the son of the emperor Tiberius is variously 'Drusus Caesar' or 'Drusus Iulius' (ind. 57), although both forms are correct. More intriguing is the fasti of Book 80. The following table provides a comparison of the book 80 fasti with two fourth century consular lists - the consular fasti found in the

${ }^{64}$ Cf. Boissevain (n.1), 2.558. Cassiodorus (Chron. 620/19 [= Chron. Min. 2. p.136]), also names the consul as C. Norbanus. The fact that Cassiodorus compiled his list either directly or indirectly from Aufidius Bassus makes the suggestion particularly tantalising. For the relationship between Cassiodorus and Aufidius Bassus, see now FRHist 3.604-5 (Levick).

${ }^{65}$ Tac. Ann. 2.41; cf. Fasti Ostienses (Inscr. It. XIII.1 p. 185), and the Fasti Antiates minores (Inscr. It. XIII.1 p. 303), name the consul 'Caelius'. Again, Cassiodorus (Chron. 618/17 [= Chron. Min. 2. p.136]) shows a closer affinity with the Dionian fasti, naming him C. Caecilius. The confusion is also present in our epigraphic sources. The Fasti Lunenses (Inscr. It. XIII.1 p. 310) too preserves the name 'Caecilius'.

${ }^{66}$ That is, a Caecilius Nepos adopted by a Caelius Rufus: cf. $P I R^{2} \mathrm{C} 141$. 
Chronograph of 354 and the fasti compiled by Theon of Alexandria some time after $372 .^{67}$

Dio



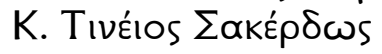

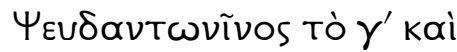



Г. ВÉttios Гра̃тos

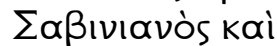

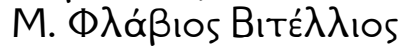

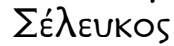

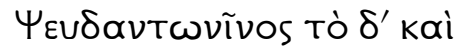

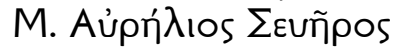

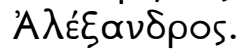

Chronograph 354

Antonino II et Sacerdote

Antonino III et

Comazonte

Grato et Seleuco

Antonino IIII et

Alexandro
Theon of Alexandria

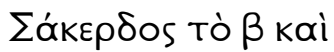

Avtúvios tò $\beta$

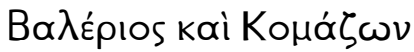

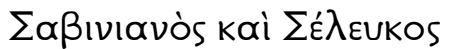

The elementary solecisms of Theon (a man of no mean intelligence) only emphasise the quality of the Dionian material. ${ }^{68}$ What is particularly striking, however, is that the author of the Dionian fasti should record the emperor as 'False Antoninus' ( $\Psi \varepsilon \cup \delta a v T \omega \nu$ IVos) one of the pejorative names given by Dio to the emperor throughout the text, but not a name (understandably) found in any other surviving

${ }^{67}$ Note that the Dionian fasti in $\mathrm{V}$ are riddled with scribal errors and have been corrected significantly by modern editors: Boissevain (n. 1), 3.452-3 (with apparatus criticus). Theon's consular fasti, preserved in one of the manuscripts of Ptolemy's Useful Tables, cover the years A.D. 138 to 372 . The only edition is that of H. Usner, printed in Chronica Minora 3. 375-381, from which the sample has been copied.

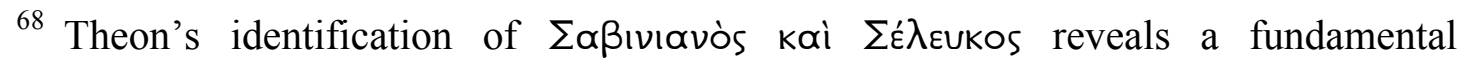
misreading of a fuller consular list, either by Theon or by an earlier compiler. 
fasti or consularia, where he appears properly as 'Antoninus' ${ }^{69}$ Again the reasons for this are obscure. It is just possible that 'Pseudantoninus' was the name found in the copy of the fasti from which the compiler worked. It is perhaps more likely that the name was interpolated into the fasti by the compiler himself. Indeed, the name Pseudantoninus for the emperor we call Elagabalus is something peculiar to Dio or the tradition derived from his work. ${ }^{70}$ Why this should happen here but not elsewhere defies ready explanation. Certainly it achieves the effect of reconciling Dio's text with that of the fasti, but it does not follow necessarily that this was the compiler's intention. ${ }^{71}$ Nowhere else does he make such concessions. ${ }^{72}$ Perhaps the compiler ${ }^{69}$ E.g. Cons. Const. [ed. Burgess (n.53), 232]; Chron. 354 [= Chron Min. 1. p. 59]; Chron. Pasch. [ed. Dindorf 1. p. 498].

70 'Pseudoantoninus' appears once in the Latin tradition. Significantly, it is not is not applied to Elagabalus, but to Diadumenianus, the son of the Emperor Macrinus (SHA Heliogab. 8.4). The closest we get to Dio's 'Pseudantoninus' is in a fragmentary quatrain from Ausonius (Caes. 138-9 [ed. Green]): Tune etiam Augustae sedis penetralia foedas, | Antoninorum nomina falsa gerens? This is, doubtless, due to the fact that a significant strain of the Latin tradition believed that Elagabalus was the child of Caracalla and thus had some claim to the name Antoninus: e.g. SHA M. Ant. 9.2; Victor Caes. 23.1; [Vict.] Epit. 23.1; but note the more agnostic statements in SHA Macr. 7.6; SHA Heliog. 1.4-2.1; Eutr. 8.22.

${ }^{71}$ Pseudantoninus is one of the several pejorative names Dio uses for the emperor (80(79).1.1). We may wonder why the compiler chose this one.

72 The obvious example among the surviving indices would be the fasti to Book 59, where the compiler names the emperor properly as either 'C. Caesar Germanicus' $(\Gamma$.




wanted to make clear a distinction between the two Antonini (i.e. Caracalla and Elagabalus) in order to avoid confusion. ${ }^{73}$ Yet another explanation is possible. If the index were composed soon after the fall of Elagabalus, then the author might have had a more emotive reason for not granting the emperor his official style, given the active damnatio memoriae. ${ }^{74}$

The indices were undoubtedly composed from sources separate from the text. But it does not necessarily preclude the possibility that Dio was their author. The differences between Dio's presentation of the consuls' names in the body text and in the indices may simply be due to the compilation of the fasti at a different time to the writing of his main narrative or from different sources, and his reluctance or inability to reconcile the two. If it was Dio's method of work to follow an earlier annalistic historian, at least so far as to provide him with the basic annalistic framework for his main narrative, then it is not difficult to see why he was reluctant to change the names of the consuls in the body text so as to conform to his independent researches in the fasti sections. Whether this procedure is plausible or not is a topic to which we now turn.

Caligula, which is supplied in both the narrative of Book 59 (59.1.1) and in the index

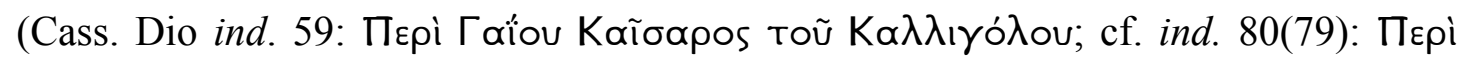

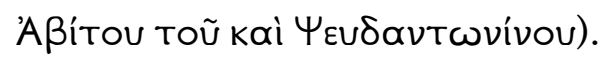

${ }^{73}$ Such as that evident in the compiler of the Chronicon Paschale, who ascribes to Caracalla the first two consulships of Elagabalus.

${ }^{74}$ For which, see M. Icks, The Crimes of Elagabalus: The Life and Legacy of Rome's Decadent Boy Emperor (London, 2011), 79-83, and especially, 87-8; cf. SHA Heliogab. 17.4. 


\section{ORIGINS}

So far, little has been said about the origins of the indices. It has been suggested elsewhere, albeit tentatively, that the Dionian indices owe their inception to what has been styled as the 'cultural salvage programme' of Constantius II and the preparation of the imperial library at Constantinople. ${ }^{75}$ While at first sight appealing, hard evidence for this is absent. Virtually nothing is known about Constantius' programme. Even the date of the completion of the famed library is controversial. ${ }^{76}$ Indeed, our evidence for such a systematic programme of copying texts rests primarily on the partial testimony of Themistius (Or. 4.59D-60C). As recognised by Alföldi, little store should be placed in portrayals of emperors as restorers of culture that appear in the fourth century panegyrists. ${ }^{77}$ Indeed, Mamertinus, writing under Julian (and with

${ }^{75}$ Swan (n. 1), 34 n. 142.

${ }^{76}$ Zosimus (3.11.3) tendentiously attributes the construction of the library to Julian: F. Paschoud, Zosime: Histoire Nouvelle, Livre III (Paris, 2003), 99. For skeletal comments on the imperial library at Constantinople, see N.G. Wilson, 'The Libraries of the Byzantine World', GRBS 8 (1967) 53-80, at 60-1; Wilson (n. 15), 50-1; Cameron (n. 41), 426. G. Cavallo 'La transmissione dei 'moderni' tra antichità tarda e medioevo bizanto', Byz.Zeit. 80 (1987), 313-29, and P. Lemerle, Le premier humanisme byzantin: notes et remarques sur enseignement et culture à Byzance des origines au Xe siècle (Paris, 1971), 54-60 = P. Lemerle (trans. H. Lindsay and A. Moffatt), Byzantine Humanism: the first phase (Canberra, 1986), 57-63 perhaps exaggerate the extent of this programme, given the slender evidence for it.

${ }^{77}$ A. Alföldi (trans. H. Mattingly), A Conflict of Ideas in the Late Roman Empire: The Clash Between the Senate and Valentinian I (Oxford, 1952), 116-17. The notion of 
perhaps an equivalent degree of mendacity to that of Themistius) presents the reign of Constantius II as a cultural wasteland (XII Pan. Lat. 3(11).23.4).

A later rescript from the reign of Valentinian, Valens, and Gratian indicates that scribes were required to copy and repair Greek and Latin manuscripts for the library at Constantinople. ${ }^{78}$ Yet, irrespective of the success (or not) of the activities of these fourth century scribes, it seems unlikely that these individuals performed the sort of work that went into composing the indices of Dio's history. Indeed, if it was in the remit of these scribes to affix indices to historical works, then we should expect to find not only greater similarity between the Dionian indices and the indices in other works, but also the existence of more indices in general.

An individual was responsible for the creation of the Dionian indices, not an institution. So much we may infer from analogous works. Where we do have evidence for the creation of prologues or summaries of ancient works, such as Libanius' hypotheses of the speeches of Demosthenes, these appear to have been private ventures. Indeed, Libanius compiled the summaries at the behest of the pro-consul of Constantinople, a certain Montius. ${ }^{79}$ The fasti sections of the indices are also suggestive of the work of one man. The compilation of such consular lists was a the ideal emperor as a patron of the arts is a familiar topos in pre-fourth century panegyric (cf. Pliny Pan. 47.1-3; [Aristid.] Or. 35.20).

${ }^{78}$ Cod. Theod. 14.9.2: Antiquarios ad bibliothecae codices componendos vel pro vetustate reparandos quattuor Graecos et tres Latinos scribendi peritos legi iubemus. This constitution, which was addressed to the urban prefect Clearchus (PLRE 1.211-2 [Clearchus 1]), is dated to 8 May 372.

${ }^{79}$ Lib. Argum. 1.1 [= ed. Foerster 8 p. 600]. Almost certainly Montius Magnus: PLRE 1. 535-6 (Magnus 11). 
difficult task and was not likely to have been the work of anonymous library functionaries in Constantinople. ${ }^{80}$ Indeed, the composition of consular lists and consularia was a high-status activity. Ausonius and Cassiodorus, for example, prepared lists of consuls as literary gifts to commemorate the consulship of an honoured friend or political ally. ${ }^{81}$

Yet, if our putative aristocratic compiler of the Dionian indices lived during the fourth or early fifth century, we might expect the fasti sections to conform more to the conventions of such lists from late Antiquity, which, as we saw above, they do not in any way. Moreover, where we do have evidence of elite fourth century 'editors' of

${ }^{80}$ Such as the Latin and Greek scribes copying texts for the library at Constantinople described in the imperial constitution mentioned above (n. 78).

${ }^{81}$ Cassiodorus seems to have prepared his work for the son in law of Theodoric, Eutharic the western consul of 519 (Cassiod. Chron. 1363/519 [= Chron. Min. 2.161]; PLRE 2. 438 [Fl. Eutharicus Cilliga]). Cf. J.J. O’Donnell, Cassiodorus (Berkeley, 1979), 36-43. Ausonius' work appears to have been intended initially for Gregorius (PLRE 1.404 [Proculus Gregorius 9]), but was rededicated to Ausonius' son, Hesperius: R.P.H. Green, The Works of Ausonius (Oxford, 1991) 554-5; cf. PLRE 1.427-428 (Decimius Hilarianus Hesperius 2). With the exception of a few dedicatory epigrams (Auson. 22 [OCT]) we know nothing for certain about the form Ausonius' Fasti took. R.W. Burgess, 'Principes cum Tyrannis: Two Studies on the Kaisergeschichte and Its Tradition', $C Q 43$ (1993), 491-500, at 495 n.18; Burgess (n. 60), 285 n. 97 contends that the work was a prose consularia - that is an annotated consular list. Green (as above, at 555; reasserted in R.P.H. Green, 'Ausonius' Fasti and Caesares Revisited', CQ 49 [1999], 573-8) believes it to have been in verse, similar to the author's Caesares. 
historical texts, the activities of these men seem to be markedly different from those of our compiler. Here again we may turn to Livy with profit. We know from a group of subscriptions found in several of the manuscripts of Books 1-9 of the Ab Urbe Condita that Livy found such aristocratic editors: ${ }^{82}$ namely the famous trio of Tascius Victorianus, Nicomachus Flavianus (the younger), and his son Nicomachus Dexter. ${ }^{83}$ These three viri clarissimi were presumably similar in rank to the sort of individual we could expect to have compiled the indices of Dio's history. Yet not one of these so-called editors of Livy produced something akin to the indices of Dio's history. Nor can we assume that this trio sought in Livy the same sorts of imperial and institutional detail noted in the Dionian indices. Indeed, it was probably for their moral or rhetorical edification that readers turned to Livy in later centuries (hence the survival of the books which we have) as it was for Dio in the Byzantine period, rather than for a history of administrative or institutional developments. ${ }^{84}$

${ }^{82}$ These men were hardly 'editors' in the modern sense of the word, nor was the result of their labours an 'edition' of Livy. For further details and discussion of these subscriptions, see J.E.G. Zetzel, 'The Subscriptions in the Manuscripts of Livy and Fronto and the Meaning of Emendatio', CPh 75 (1980), 38-59, especially 38-49; Cameron (n. 41), 498-526; cf. C.W. Hendrick, History and Silence: Purge and Rehabilitation of Memory in Late Antiquity (Austin, 2000) 177-190.

${ }^{83}$ PLRE 2.1160-1 (Tascius Victorianus 2); PLRE 1.345 (Nicomachus Flavianus 14); PLRE 2.357-8 (Appius Nicomachus Dexter 3).

${ }^{84}$ For Livy as a source of moral exempla for late-Antique authors, see R.M. Ogilvie, The Library of Lactantius (Oxford, 1978) at 42-3. But Cameron (n. 41), 511-13, notes how relatively few authentic references to Livy occur in both non-Christian and Christian authors of the fourth and fifth centuries. 
The nature of the manuscript transmission should also make us wary of a fourth or fifth century date for the creation of the indices. Had the indices been compiled at some time during the late fourth or early fifth centuries, the existence of $\mathrm{V}$ becomes difficult to explain. The only solution would be that several copies of Dio's text were made in Constantinople, or a similar centre, and one of these copies was then transported to Italy which in turn formed the exemplar for $\mathrm{V}$ which was copied perhaps only a matter of decades later. Yet this is hardly satisfying. From what we know of the copying activities of the library at Constantinople, the editions that were prepared were for the use in the library itself, not for widespread dissemination. Similarly if the indices were the product of an unknown aristocrat of the same period, then we are left with the problem of how the indices should have entered the tradition in both eastern (M and L) and western manuscripts (V). The circulation of these private texts would be limited. We may recall the subscriptions in the Livian manuscripts, where it is worth noting that only a fraction of the total carry the Nicomachean subscriptions.

Others have suggested that the indices originated closer to the time of the composition of the history itself. ${ }^{85}$ Such a view is to be preferred. As suggested above, the evidence of the fasti is at least suggestive of a third century date. Moreover, the Dionian fasti are likely to have derived from full, predominately Latin sources, the likes of which are unlikely to have been widely accessible outside Rome or Italy. The Italian connection may be seen in the compiler's adoption of that blunt Latinism

\footnotetext{
${ }^{85}$ Cf. Favuzzi (n. 5); Mazzucchi (n. 14), 119. A.E. Egger, Examen critique des historiens anciens de la vie et du règne d'Auguste (Paris, 1844), 286, drawing on analogy with the indices of Gellius and the elder Pliny, asserted that Dio himself was the author of the indices.
} 
Kepєádıı for the (aediles) Cereales in place of the stylistically self-conscious periphrasis found in the body text. Here we may infer not only the bilingualism of the compiler, but also the assumption that the reader would recognize what was meant by the term. Again, the compiler's attention to the introduction of the various administrative posts also suggests a third rather than fourth century date. Dio's account of the disposition of the legions (as we have seen, duly recorded in the index to Book 55) was intended for a Severan audience, ${ }^{86}$ and would have had little immediate value in even the later third century, let alone the subsequent ones. The same goes for the other administrative developments listed in the indices.

We may also ask why would a mid- or late-fourth century reader be interested in the vigiles, when the brigade had seemingly long fallen into abeyance ${ }^{87}$ Then again, what third century reader would be interested in these administrative developments? The question of Dio's putative audience has been dealt with at length by others and only brief comment is needed here. ${ }^{88}$ Arguing from the instances of Dio's 'elementary' descriptions of political institutions, Aalders contended that if Dio envisioned a reading public then it comprised 'ordinary Greeks' who lacked basic knowledge of Roman institutions. ${ }^{89}$ This argument is not convincing. After all, it was

${ }^{86}$ For which, see Swan (n. 1), 158-72.

${ }^{87}$ It is likely that the vigiles ceased to exist by the early fourth century: C. Furhmann, Policing the Roman Empire: Soldiers, Administration, and Public Order (Oxford, 2011), 132.

${ }^{88}$ Dio's own statement on the question of his audience is suitably vague: Cass. Dio F.

1.1 .

${ }^{89}$ G.J.D. Aalders, 'Cassius Dio and the Greek World', Mnemosyne 39 (1986), 282304, at 291. 
an affectation of later Greco-Roman historiography to provide definitions of nonClassical institutions or words for stylistic or rhetorical purposes. ${ }^{90}$ The contentions of Martin Hose and Alain Gowing (and others) are more convincing: that Dio wrote for an essentially senatorial audience. ${ }^{91}$ The evidence of the indices might lend further support to such a reading. References to the landmarks of Rome would have offered such a reader a handbook to interpreting the city and the history of its monuments. Again, the institutional focus displayed in the summaries would be perhaps most congenial to a reader who, like Dio, was interested in the origins of the organs of the Roman administration. In this regard we may draw a loose parallel between the Dionian indices and the sorts of administrative handbooks, such as the Enchiridion of

${ }^{90}$ For this affectation, see the comments of A. Cameron, Agathias (Oxford, 1970), 7588 (on Agathias); and P.A. Stadter 'Plutarch's Lives and their Roman Readers', in E.N. Ostenfeld, (ed.), Greek Romans and Roman Greeks: Studies in Cultural Interaction (Aarhus, 2002), 123-35, at 123-4; reiterated in P.A. Stadter, Plutarch and his Roman Readers (Oxford, 2014), 45-6 (on Plutarch).

${ }^{91}$ A.M. Gowing, The Triumviral Narratives of Appian and Cassius Dio (Ann Arbor, 1992), 292-4; M. Hose, Erneuerung der Vergangenheit: die Historiker im Imperium Romanum von Florus bis Cassius Dio (Stuttgart, 1994), 421. This conforms to what we know about the circulation of literary texts in the Roman world. As noted by R.J. Starr, 'The Circulation of Literary Texts in the Roman World', CQ 37 (1987), 213-23, works were circulated initially amongst the author's close friends. Cf. W.A. Johnson, Readers and Reading Culture in the High Roman Empire: A Study of Elite Communities (Oxford, 2010), 85-8. 
the second century jurist Pomponius, which provided an historical outline of the various Roman magistracies. ${ }^{92}$

\section{AUTHORSHIP}

By way of conclusion, some thoughts on the function and authorship of indices may be offered. As the foregoing discussion has suggested, it seems probable that the indices were created in the early third century, perhaps to adorn a deluxe edition of Dio's work. The form this early edition took is not clear, but the possibility that it was in the form of a series of codices cannot be ruled out, at least on codicological grounds. ${ }^{93}$ It was from this that other copies were made. The summaries provided the reader with not so much a précis of Dio's narrative but a concordance to the growth of the Roman Empire, its administration, the city of Rome, and an outline of the careers

${ }^{92}$ For Pomponius and his Enchiridion, see D. Nörr, 'Pomponius oder "Zum Geschichtsverständnis der römischen Juristen"”, ANRW 2.15 (1975), 497-604, at 51239. Note also the comments of A.M. Kemezis, Greek Narratives of the Roman Empire under the Severans: Cassius Dio, Philostratus, and Herodian (Cambridge, 2014), $137-8$, on Dio's keen interest in the history of senatorial magistracies.

${ }^{93}$ Cf. Mazzucchi (n. 14), 120 who suggests rolls rather than codices. Codices were becoming increasingly common from the second century onwards: L.D. Reynolds and N.G. Wilson (edd.), Scribes and Scholars: A Guide to the Transmission of Greek and Latin Literature (Oxford, 2013 ${ }^{4}$ ), 34-5. For a partial survey of known early codices, see E.G. Turner, The Typology of the Early Codex (Philadelphia, 1977), 89-100. 
of its statesmen. In a world before standardised pagination, ${ }^{94}$ and in the absence of marginal capitula, ${ }^{95}$ these summaries were intended to inform (or to remind) the reader of the contents of a particular book rather than of a precise passage within the individual book. The notation of several speeches in the summaries suggests that the compiler had in mind the possibility that portions of the work would be performed, either in a public or private setting. ${ }^{96}$ But on the whole the tenor of the summaries suggests that it was a private rather than public readership that the compiler expected.

It cannot be determined with certainty whether the fasti and temporal statements were compiled before, after, or at the same time as the summaries. Nevertheless it is likely that they were introduced into the indices at an early stage. These lists provided the reader with a way of orientating the summaries to a general conception of time. They were also a unique feature of the work, a statement of the erudition of the author. Moreover, if the fasti continued down to the end of the work as we have it, ${ }^{97}$ Dio's own name would have been the last to appear on the fasti,

${ }^{94}$ For comments on where we do have pagination in early codices or the numbering of columns in rolls, see Turner (n. 21), 16.

95 The marginalia of $\mathrm{V}$ provides a partial concordance with the material provided in the summary. However, these notes were added at a later date by a reader other than the copyist.

${ }^{96}$ For reading habits, see now Johnson (n. 91).

${ }^{97} \mathrm{Cf}$. Favuzzi (n. 5) who argues that the index to Book 80(79) was the final index, and that the work originally terminated with the accession of Alexander Severus in A.D. 222. Photius (Bib. cod. 71) knew of Dio's work in an eighty-book edition, which concluded with the death of Elagabalus, although the patriarch shows knowledge of Dio's appendix-like summary of the reign of Alexander Severus down to A.D. 229. 
presenting, by either happy coincidence or design, the consular historian at the end of a long line illustrious names, the spiritual descendant of Brutus and Collatinus.

What then may be said of the identity of our compiler? It is tempting to posit an Ignotus. This man desired to introduce into his text of Dio's monumental history a series of indices which would serve to direct him to specific books that contained material that was of interest. He augmented these summaries with a detailed consular list which he meticulously divided so as to synchronise each book with an official reckoning of time. Furthermore, we may divine something of Ignotus' background from his selection and presentation of material. He was indubitably a member of the amplissimus ordo, bi-lingual, and a man with a strong antiquarian bent, who probably compiled the indices before the middle of the third century. In other words, Ignotus was a man not unlike Dio himself. Do we need this phantom intermediary? I would suggest not. The compiler can indeed be Dio himself.

If we accept that the indices originated with the Roman History itself, then the problem posed by $\mathrm{V}$ dissolves. Upon completing his history, Dio had several copies of the work made, which were intended for circulation amongst his friends. No doubt some of these friends hailed from the eastern provinces, like Dio himself. Yet some undoubtedly lived in Rome and Italy, where Dio lived for most of his career. ${ }^{98}$ It is perhaps from a copy of his work sent to one of his friends in Rome, that $\mathrm{V}$ is descended.

Such a conclusion is controversial. For some, it is no doubt disappointing as well. Had our putative Ignotus compiled the indices, we would have a clearer glimpse at the early reception and transmission of Dio's history. What this article has shown, however, is that there is nothing to preclude Dio from being the author of the indices.

\footnotetext{
${ }^{98}$ For Dio's residence in Italy (Capua), see 77(76).2.1; cf. Millar (n. 40), 10-11.
} 
If the assertion is correct and Dio was the author of the indices, then we need perhaps to start thinking about Dionian indices as being more integral parts of Dio's composition: texts that were intended by the author himself to be read in conjunction with the body text. Although the precise function of these idiosyncratic indices remains elusive, the indices are still 'good to think with', in so far as they represent an early attempt, probably by the author himself to condense and order his work. Should others wish to reassert a later date for the composition of these indices, hard evidence needs to be adduced, rather than reliance on the weight of tradition or scholarly inertia. At very least, Dio's future editors or commentators can no longer choose to ignore these unique paratexts.

Wadham College, Oxford C.T. MALLAN

ctmallan01@gmail.com 